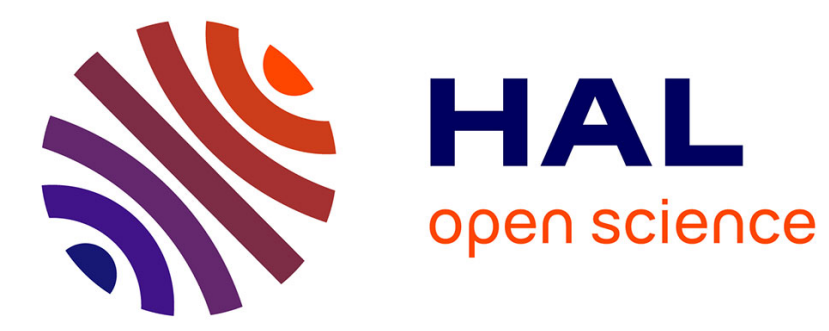

\title{
Cancer stem cells: Beyond Koch's postulates
}

Emmanuel Garcion, Philippe Naveilhan, François Berger, Didier Wion

\section{To cite this version:}

Emmanuel Garcion, Philippe Naveilhan, François Berger, Didier Wion. Cancer stem cells: Beyond Koch's postulates. Cancer Letters, 2009, 278 (1), pp.3-8. 10.1016/j.canlet.2008.09.006 . inserm01194481

\section{HAL Id: inserm-01194481 https://www.hal.inserm.fr/inserm-01194481}

Submitted on 7 Sep 2015

HAL is a multi-disciplinary open access archive for the deposit and dissemination of scientific research documents, whether they are published or not. The documents may come from teaching and research institutions in France or abroad, or from public or private research centers.
L'archive ouverte pluridisciplinaire HAL, est destinée au dépôt et à la diffusion de documents scientifiques de niveau recherche, publiés ou non, émanant des établissements d'enseignement et de recherche français ou étrangers, des laboratoires publics ou privés. 


\title{
Cancer stem cells: beyond Koch's postulates.
}

\author{
Emmanuel Garcion, Philippe Naveilhan, François Berger*, \\ Didier Wion $*^{\circledR}$.

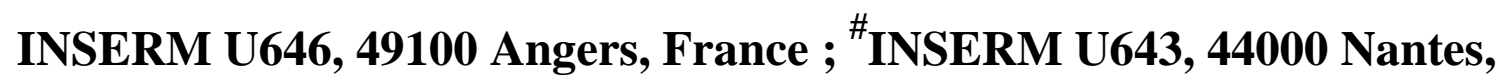 \\ France ; *INSERM U836, 38706 La Tronche, France.
}

@ corresponding author: didier.wion@ujf-grenoble.fr

\begin{abstract}
Until the last century, infectious diseases were the leading cause of human mortality. Therefore, our current medical reasoning is profoundly influenced by views that originated from medical microbiology. The notion that cancer growth is sustained by a subpopulation of particular cells, the cancer stem cells, is highly reminiscent of the germ theory of disease as exemplified by Koch's postulates in the $\mathrm{XIX}^{\text {th }}$ century. However, accumulating data underscore the importance of cell-cell interactions and tumor environment. Hence it is essential to critically review the basic tenets of the cancer stem cell concept on the light of their relationships with Koch's postulates. Shifting the pathogenic element from a special cellular entity (cancer stem cell or microorganism) to a "pathogenic field" could be critical for curing both cancer and drug-resistant infectious diseases.
\end{abstract}

Keywords: cancer; cancer stem cell; Koch's postulates; targeted therapies. 


\section{Introduction.}

In recent years, accumulating experimental evidence has been presented demonstrating that solid tumor growth is driven by a small subset of cancer cells, the cancer stem cells [1-3]. These cells are defined as self-renewing cells responsible for maintaining cancer growth and for producing differentiated progeny that form the bulk of the tumor [4]. The cancer stem cell concept has an immediate therapeutic consequence: if cancer growth is sustained exclusively by rare cancer stem cells, then curative therapy will require targeting this cell population. Therefore, it is critical to fully characterize these cells. Cancer stem cells can be prospectively isolated by flow cytometry on their ability to outflow Hoechst 33342 (SP phenotype) or on the basis of cell surface markers expression [5-13]. For example, the cancer stem cell population is defined as $\mathrm{CD}_{133^{+}}$in brain tumors [5], CD133 ${ }^{+}[6,7]$ or EpCAMhigh/CD $44^{+} / \mathrm{CD} 166^{+}$in colon cancer [8], $\mathrm{CD} 44^{+} / \mathrm{CD} 24^{-/ \text {low }} /$ Lineage $^{-}$in breast tumors [9], and $\mathrm{CD}^{+} 4^{+} / \mathrm{CD} 117^{+}$in ovarian tumors [10]. The experimental procedure to identify cancer stem cells is: i) their isolation from patients, ii) their growth or selection in pure culture and, iii) serial reproduction of the disease by their inoculation into animals (experimental tumors should be a phenocopy of the original tumor) (Fig. 1A). Nevertheless, although subpopulations of tumorigenic cancer cells with self-renewal and differentiation capacities have been characterized in leukaemia and several solid tumors, the cancer stem cell concept remains controversial [14-18]. Indeed, recent data have raised concerns about the use of Hoechst dye exclusion to define cancer stem cells [19-23], and CD133 negative cells have recently been described as tumorigenic in brain and colon tumors [24-26]. 


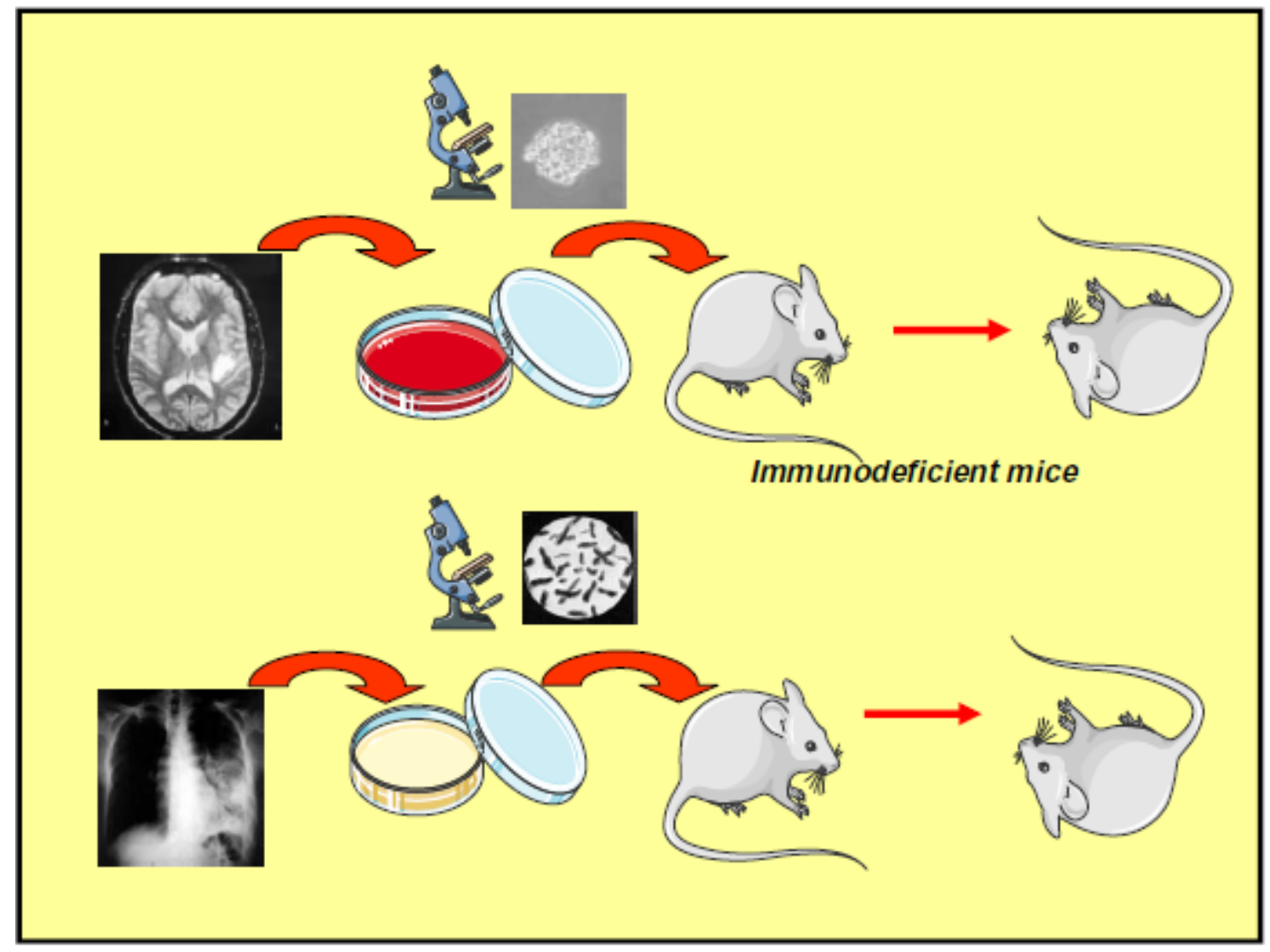

Fig 1

\section{Cancer stem cell and Koch's postulates.}

Experimental steps, used to characterize cancer stem cells, follow the logic diagram used to establish a causal relationship between a bacteria and a disease. However, are cancer and infectious diseases bio-logically equivalent?

\section{Koch's postulates.}

Koch's postulates were derived in the late $19^{\text {th }}$ century from work on infectious diseases, and then they have been extensively used for proving disease causation by microbes. The three basic principles of Koch's postulates, as they have been presented in 1890 before the Tenth International Congress of Medicine in Berlin can be summarized as shown in Box 1 [27-29]. However, although Koch's postulates were devised as general guidelines to identify infectious microbes, these criteria have several limitations, some of them already noticed by Koch 
himself. Thus, polymicrobial infections do not comply with Koch's principles [30]. Other well-known examples of Koch's postulates limitations are when the pathogenic microorganism cannot be grown in pure culture [31], or when there is no animal model for the corresponding infection [28]. These limitations must be noticed as Koch's postulates are still sometimes implicitly used for determining causation in medicine. Indeed, as previously noted by Fredricks and Relman, "in certain diseases, the blind adherence to Koch's postulates may act as an hindrance instead of an aid" [28].

\section{Koch's postulates}

The parasite occurs in every case of the disease in question and under circumstances which can account for the pathological changes and clinical course of the disease.

The parasite occurs in no other disease as a fortuitous and non pathogenic parasite.

After being fully isolated from the body and repeatedly grown in pure culture, the parasite can induce the disease anew.

\section{Koch's postulates and cancer stem cell.}

Since they have been stated in 1890, the guidance of Koch's postulates have been consciously or unconsciously used or adapted to establish causation in many diseases not related to bacterial infection [28], and it is notable that Koch's postulates have been rationalized to explain the role of viruses in cancer [32]. Now, regarding their influence in cancer stem cell research, it is note worthy that if we replace the term "microorganisms" with the term "cancer stem cell" in the criteria presented Box 1, then the experimental procedure used to characterize cancer stem cells restate Koch's postulates, as they have been used to identify the causative agent in an infectious disease such as tuberculosis (Fig 1B). Indeed, this finding is 
not surprising since these postulates are now an implicit guideline for demonstrating causality in occidental biological medicine. As a matter of fact these experimental procedures have been successfully used for characterizing cancer stem cells in leukaemia and several solid tumors. However, validation of the cancer stem cell paradigm through Koch's criteria has also some limitations.

\section{$\underline{\text { Revisiting the cancer stem cell concept in the light of Koch's postulates limitations. }}$}

Limitations of Koch's postulates in cancer research are similar to those observed for infectious diseases. For example, cell culture conditions used to expand cancer cells can select for cancer cells not representative to those found in the original tumor [33] or can be inadequate for maintaining some critical cancer cell subpopulations [34]. Koch's postulates have also limitations when they are used in complex diseases with multi-causal chains. This has been described for polymicrobial diseases but is also evident in cancer research. For example, let us consider a tumor xenograft experiment with a cancer cell which requires two factors " $x$ " and " $y$ " for sustaining tumor growth (Fig 2). In Fig 2 A, the cancer cell produces both of these factors, and is therefore capable of supporting cancer growth. In this model, the "cancer stem cell" function is attributable to a cell entity, the cancer stem cell, which can be viewed as an infectious micro-organism or a pathogenic corpuscle. Here, the cancer stem cell fulfills Koch's postulates, and this model squares with the germ theory of disease. In other words, the cancer stem cell is necessary and sufficient for sustaining tumor growth, and the "cancer stem cell" function is attributable to this cell entity. On the contrary, in Fig. 2B, the cancer cell is deficient in one factor. Therefore, cooperation between the cancer cell and another cancer or stromal cell is required for sustaining tumor growth [35]. In this model, each cell is necessary but not sufficient, and no individual cell fulfills Koch's postulates. The "cancer stem cell" function is no longer attributable to a single cell entity or pathogenic 
corpuscle but corresponds to a tumorigenic field ascribable to the tumor niche. In accordance with this model, accumulating evidence demonstrates that the stromal environment supports tumor growth and promotes invasion through, for example, stimulation of cancer cell proliferation or activation of angiogenesis [36-40]. Hence, in this model, cancer does not integrate well with the paradigm provided by Koch's postulates. Indeed, a similar limitation of Koch's postulates is found for polymicrobial infections that do not comply with Koch's principles [30]. Accordingly, the success of Koch's postulates in medical microbiology is due to the fact that most infectious diseases are monomicrobial. However, at the time of diagnosis, cancer is a complex multi-cellular disease containing multiple sub-clones [41,42]. Nevertheless, it must be noticed that the two models are not mutually exclusive. Regarding now the third postulate (transmission of disease by implantation of pathogen), it is related to the natural course of contagious diseases, and is therefore both experimentally and biologically relevant for these diseases. However, although viral infections contribute to 15$20 \%$ of all human cancers [43], this disease is not usually considered as contagious. Thus, when considering the cancer stem cell concept, this postulate is experimentally valid since tumors can be serially transplanted in animals via cancer stem cell implantation, but it could be bio-logically questionable since cancer stem cells are not naturally contagious. In a sense, the experimental paradigm of tumor cell implantation does not replicate the original disease but only some of its symptoms. Some of them (tumor angiogenesis, hypoxia...) are biologically relevant as they reproduce the natural features of the disease. Accordingly, they produce valid concepts which in turn provide therapeutic breakthroughs such as antiangiogenic therapies. Other experimental features, such as the serial propagation of the disease through cell implantation in animals, although experimentally useful do not strictly belong to the natural course of the disease. Hence, their use for validating a concept such as the cancer stem cell concept could be debatable. Indeed, the missing evidence in the cancer 
stem cell experimental paradigm is the cure of the natural disease following eradication of the experimentally defined "cancer stem cell".

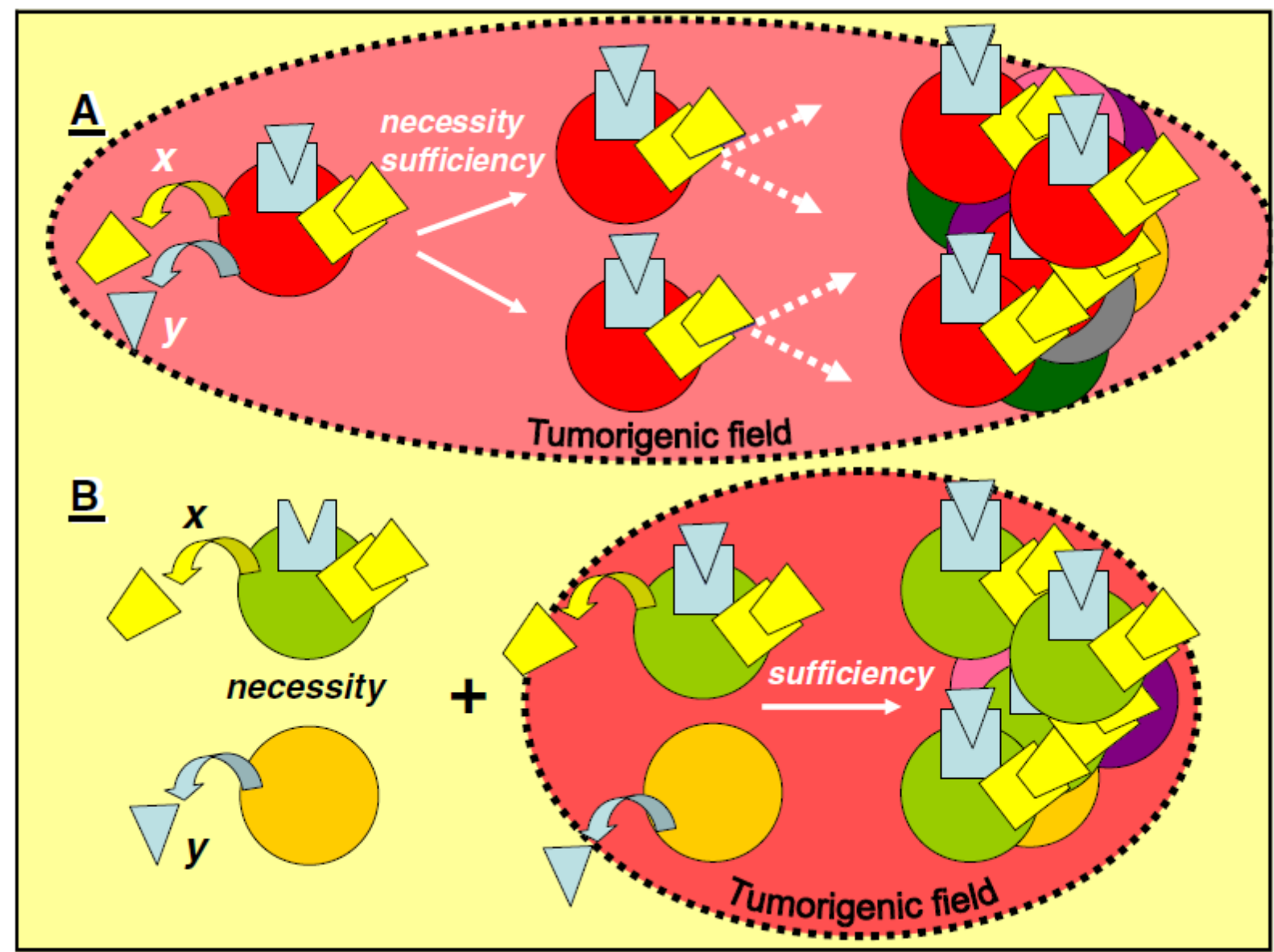

Fig 2

Tumorigenic corpuscle versus tumorigenic field.

In A, "cancer stem cell" function is borne by a cell entity or corpuscle, the cancer stem cell, which experimentally is both necessary and sufficient for sustaining tumor growth.

In B, (adapted from ref 35) "cancer stem cell" function is borne by a tumorigenic field made by the whole cancer cell environment (hormones, growth factors, extra-cellular matrix, cell interactions, angiogenesis, stromal cells...). Cancer cells are necessary but not sufficient. No single cancer cell fulfills the sufficiency criteria of a "cancer stem cell", and stromal cells are potential valuable therapeutic targets. Moreover, microenvironment can contribute both positively or negatively to tumor growth [49-52]. Both models are supported by numerous experimental evidences and they are not mutually exclusive.

\section{Cancer stem cell: beyond Koch's postulates.}


Although parallels are often made between normal stem cell and cancer stem cell [44], the experimental paradigm used for characterizing cancer stem cells is also directly related to Koch's principles. Questioning the fundamental limitations and validity of this guideline in cancer research is therefore required for designing novel experimental paradigms which are urgently need if we want to cure cancer. Thus, because of Koch's postulates limitations, the very idea of cancer, as well as current experimental approaches, could be reconsidered on the basis of a new notion of causality going beyond the characterization of a transferable pathogenic entity as defined in the germ theory of disease. This can be viewed as an extension of the Paget's "seed and soil" proposal [45]. In fact, the concept that tumorigenicity is driven by multicellular units, or cancer cell societies rather than by a special cell entity, is supported by numerous experimental evidence $[18,36-40]$. Cancer has also been viewed as a problem of tissue organization in the tissue organization field theory (TOFT) [46,47]. All these different models suggest that in solid cancer, tumor growth is an emerging function not only sustained by rare cancer stem cell but also by the existence of a complex network of interactions generating a tumorigenic field [36-40, 45-48]. This complex network of interactions includes many non-tumoral cell types (fibroblasts, lymphocytes, macrophages, endothelial cells...) which are involved in the maintenance, the progression and the growth of the tumor [36-40,45-53]. This critical role of tumor environment does not exclude the existence in the tumor mass of cancer stem cells fulfilling Koch's postulates and able to regrow a tumor outside of the tumor niche, since such cells have been experimentally characterized. Nevertheless, these cancer stem cells should not be considered as the only cancer cells able to sustain tumor growth. Indeed, a recurrent question is to know if xenograft experiments does not select only the subset of cancer cells capable to engraft and to grow in the environment provided by the non-tumoral immunodeficient mice tissue where they are implanted $[14,16,26]$. Hence, the major drawback of the cancer cell implantation assay in 
immunocompromised animals is that this assay can fail to detect human cancer cell populations unable to comply with Koch's postulates but nevertheless capable to sustain tumor growth in patients $[14,16,26]$.

\section{Towards new therapeutic paradigms.}

Another important point is that concepts from medical microbiology not only influence our way of reasoning through Koch's postulates, but also govern our cancer therapeutic approaches. Thus, ablating infectious foci to limit microbial extension (tuberculosis lobectomy, amputation) is conceptually similar to tumor excision. Likewise, antimicrobial and anticancer chemotherapies which generally target individual causative agents are similar in their design and also their limitations. Indeed, emergence of bacterial strains resistant to available antibiotics is one of the current medical challenges just like drug-resistant cancer cells are. Targeting the microbiological niche, which also includes non-pathogenic host cells, is an alternative to present antimicrobial therapies. This could be done for example by targeting bacterial virulence rather than bacterial vital cellular processes [54]. Likewise, in cancer, anti-angiogenic therapies target stromal cells rather than cancer cells. Indeed more than 20 drugs targeting different cells in the microenvironment are currently in clinical trials for cancer $[48,49]$. Hence the possibility, after more than one century of Koch's postulates hegemony, of resuming both infectious and cancer therapies into a "therapeutic field" unifying paradigm in which the sufficient and necessary pathogenic cell as defined in monomicrobial disease or in the cancer stem cell paradigm is no longer the only therapeutic target.

\section{Concluding remarks}


Until the last century, humanity has been challenged with contagious disease as the leading cause of mortality. Hence, our current medical reasoning is profoundly influenced by views that originated from medical microbiology. The notion that cancer growth is maintained by a sub-population of particular cells, the cancer stem cells, is rooted in pathogen-centered views of microbial pathogenesis. Industrial countries are now confronted with cancer as one of the leading causes of mortality. However, it is not sure that views born in the biological and historical context of monomicrobial infection are fully adequate for curing this disease which is often non-contagious and which requires interactions between both normal cells and genetically and epigenetically unstable cancer cell populations. Indeed, accumulating data suggest that therapeutic targeting must also include tumor microenvironment $[40,49,50]$. Therefore, the possibility that Koch's postulates act as a cultural archetype in cancer research should be considered. Indeed, the reductionist and oversimplified cancer stem cell paradigm which originates from the implicit application of Koch's postulates should progressively evolve towards a "tumorigenic field" concept, just as the "one gene - one protein - one phenotype" paradigm has evolved towards epistasis [55]. This does not deny the importance of this guideline in the discovery of some fundamental aspects of cancer, such as the existence of oncogenic virus or the characterization of cancer cells with experimental stem-like features. However cancer research needs now to go beyond Koch's postulates for opening the way to new experimental and therapeutic paradigms.

\section{Conflict of interest.}

The authors declare no conflict of interest.

\section{References.}

[1] M.S. Wicha, S. Liu, and G. Dontu, Cancer stem cells: an old idea--a paradigm shift. Cancer Res. 66 (2006) 1883-1890. 
[2] C. Tang, B.T. Ang, and S. Pervaiz, Cancer stem cell: target for anti-cancer therapy. Faseb J. 21 (2007) 3777-3785.

[3] I. Sanchez-Garcia, C. Vicente-Duenas, and C. Cobaleda, The theoretical basis of cancer-stemcell-based therapeutics of cancer: can it be put into practice? Bioessays 29 (2007) 1269-1280.

[4] Smith A. A glossary for stem-cell biology. Nature 2006; 441: 1060.

[5] S.K. Singh, C. Hawkins, I.D. Clarke, J.A. Squire, J. Bayani, T. Hide, R.M. Henkelman, M.D. Cusimano, and P.B. Dirks, Identification of human brain tumour initiating cells. Nature 432 (2004) 396-401.

[6] L. Ricci-Vitiani, D.G. Lombardi, E. Pilozzi, M. Biffoni, M. Todaro, C. Peschle, and R. De Maria, Identification and expansion of human colon-cancer-initiating cells. Nature 445 (2007) $111-5$.

[7] C.A. O'Brien, A. Pollett, S. Gallinger, and J.E. Dick, A human colon cancer cell capable of initiating tumour growth in immunodeficient mice. Nature 445 (2007) 106-10.

[8] P. Dalerba, S.J. Dylla, I.K. Park, R. Liu, X. Wang, R.W. Cho, T. Hoey, A. Gurney, E.H. Huang, D.M. Simeone, A.A. Shelton, G. Parmiani, C. Castelli, and M.F. Clarke, Phenotypic characterization of human colorectal cancer stem cells. Proc Natl Acad Sci U S A 104 (2007) 10158-63.

[9] M. Al-Hajj, M.S. Wicha, A. Benito-Hernandez, S.J. Morrison, and M.F. Clarke, Prospective identification of tumorigenic breast cancer cells. Proc Natl Acad Sci U S A 100 (2003) 3983-8.

[10] S. Zhang, C. Balch, M.W. Chan, H.C. Lai, D. Matei, J.M. Schilder, P.S. Yan, T.H. Huang, and K.P. Nephew, Identification and characterization of ovarian cancer-initiating cells from primary human tumors. Cancer Res 68 (2008) 4311-20.

[11] C. Wu and B.A. Alman, Side population in human cancers. Cancer Lett. 268 (2008) 1-9.

[12] T. Kondo, T. Setoguchi, and T. Taga, Persistence of a small subpopulation of cancer stem-like cells in the C6 glioma cell line. Proc. Natl. Acad. Sci. U S A 101 (2004) 781-786. 
[13] C. Hirschmann-Jax, A.E. Foster, G.G. Wulf, J.G. Nuchtern, T.W. Jax, U. Gobel, M.A. Goodell, and M.K. Brenner, A distinct "side population" of cells with high drug efflux capacity in human tumor cells. Proc. Natl. Acad. Sci. U S A 101 (2004) 14228-14233.

[14] R.P. Hill, Identifying cancer stem cells in solid tumors: case not proven. Cancer Res. 66 (2006) 1891-510.

[15] D. Wion, and F. Berger, Cancer stem cells. N. Engl. J. Med. 355 (2006) 2703

[16] P.N. Kelly, A. Dakic, J.M. Adams, S.L. Nutt, and A. Strasser, Tumor growth need not be driven by rare cancer stem cells. Science 317 (2007) 337.

[17] L.L. Campbell, and K. Polyak, Breast tumor heterogeneity: cancer stem cells or clonal evolution? Cell Cycle 6 (2007) 2332-2338.

[18] J. Rak, Is cancer stem cell a cell, or a multicellular unit capable of inducing angiogenesis? Med. Hypotheses 66 (2006) 601-604.

[19] D. Adamski, J.F. Mayol, N. Platet, F. Berger, F. Herodin, and D. Wion, Effects of Hoechst 33342 on C2C12 and PC12 cell differentiation. FEBS Lett. 581 (2007) 3076-3080.

[20] N. Platet, J.F. Mayol, F. Berger, F. Herodin, and D. Wion, Fluctuation of the SP/non-SP phenotype in the C6 glioma cell line. FEBS Lett. 581 (2007) 1435-1440.

[21] X. Zheng, G. Shen, X. Yang, and W. Liu, Most C6 cells are cancer stem cells: evidence from clonal and population analyses. Cancer Res. 67 (2007) 3691-3697.

[22] Y. Zhong, C. Zhou, W. Ma, D. Wang, S. Guo, X. Su, and S. Zhang, Most MCF7 and SK-OV3 cells were deprived of their stem nature by Hoechst 33342. Biochem. Biophys. Res. Commun. 364 (2007) 338-343.

[23] U.D. Lichtenauer, I. Shapiro, K. Geiger, M. Quinkler, M. Fassnacht, R. Nitschke, K.D. Ruckauer, and F. Beuschlein, Side population does not define stem cell-like cancer cells in the adrenocortical carcinoma cell line NCI h295R. Endocrinology 196 (2007) 1314-1322 . 
[24] J. Wang, P.O. Sakariassen, O. Tsinkalovsky, H. Immervoll, S.O. Boe, A. Svendsen, L. Prestegarden, G. Rosland, F. Thorsen, L. Stuhr, A. Molven, R. Bjerkvig, and P.O. Enger, CD133 negative glioma cells form tumors in nude rats and give rise to CD133 positive cells. Int. J. Cancer 122 (2008) 761-768.

[25] A.T. Ogden, A.E. Waziri, R.A. Lochhead, D. Fusco, K. Lopez, J.A. Ellis, J. Kang, M. Assanah, G.M. McKhann, M.B. Sisti, P.C. McCormick, P. Canoll, and J.N. Bruce, Identification of A2B5+CD133- tumor-initiating cells in adult human gliomas. Neurosurgery $62(2008) 505-514$.

[26] S.V. Shmelkov, J.M. Butler, A.T. Hooper, A. Hormigo, J. Kushner, T. Milde, R. St Clair, M. Baljevic, I. White, D.K. Jin, A. Chadburn, A.J. Murphy, D.M. Valenzuela, N.W. Gale, G. Thurston, G.D. Yancopoulos, M. D'Angelica, N. Kemeny, D. Lyden, and S. Rafii, CD133 expression is not restricted to stem cells, and both CD133+ and CD133- metastatic colon cancer cells initiate tumors. J Clin Invest 118 (2008) 2111-20.

[27] Koch R. 1891. Uber bakteriologische Forschung Verhandlung des X Internationalen Medichinischen Congresses, Berlin, 1, 35. August Hirschwald, Berlin. Xth International Congress of Medicine, Berlin, 1890.

[28] D.N. Fredericks, and D.A. Relman, Sequence-based identification of microbial pathogens: a reconsideration of Koch's postulates. Clin. Microbiol. Rev. 9 (1996) 18-33.

[29] A.S. Evans, Causation and disease: the Henle-Koch postulates revisited. Yale J. Biol. Med. 49 (1976) 175-195.

[30] H.D. Isenberg, Pathogenicity and virulence: another view. Clin. Microbiol. Rev. 1 (1988) 4053.

[31] T.M. Rivers, Viruses and Koch's Postulates. J. Bacteriol. 33 (1937) 1-12.

[32] Y. Valladares, Forms of the cancerigenic principle, cell clones, and Koch's postulates. Med. Pharmacol. Exp. Int. J. Exp. Med. 16 (1967) 462-480. 
[33] Lee, S. Kotliarova, Y. Kotliarov, A. Li, Q. Su, N.M. Donin, S. Pastorino, B.W. Purow, N. Christopher, W. Zhang, J.K. Park, and H.A. Fine, Tumor stem cells derived from glioblastomas cultured in bFGF and EGF more closely mirror the phenotype and genotype of primary tumors than do serum-cultured cell lines. Cancer Cell 9 (2006) 391-403.

[34] N. Platet, S.Y. Liu, M.E. Atifi, L. Oliver, F.M. Vallette, F. Berger, and D. Wion, Influence of oxygen tension on CD133 phenotype in human glioma cell cultures. Cancer Lett. 258 (2007) 286-90.

[35] R. Axelrod, D.E. Axelrod, and K.J. Pienta, Evolution of cooperation among tumor cells. Proc. Natl. Acad. Sci. U S A 103 (2006) 13474-13479.

[36] E. Laconi, The evolving concept of tumor microenvironments. Bioessays 29 (2007) 738-744.

[37] L. Li, and W.B. Neaves, Normal stem cells and cancer stem cells: the niche matters. Cancer Res. 66 (2006) 4553-4557.

[38] A.E. Karnoub, A.B. Dash, A.P. Vo, A. Sullivan, M.W. Brooks, G.W. Bell, A.L. Richardson, K. Polyak, R. Tubo, and R.A. Weinberg, Mesenchymal stem cells within tumour stroma promote breast cancer metastasis. Nature 449 (2007) 557-563.

[39] M.P. Shekhar, R. Pauley, and G. Heppner, Host microenvironment in breast cancer development: extracellular matrix-stromal cell contribution to neoplastic phenotype of epithelial cells in the breast. Breast Cancer Res. 5 (2003) 130-135.

[40] M.M. Mueller, and N.E. Fusenig, Friends or foes - bipolar effects of the tumour stroma in cancer. Nat. Rev. Cancer. 4 (2004) 839-849.

[41] K.M. Joo, S.Y. Kim, X. Jin, S.Y. Song, D.S. Kong, J.I. Lee, J.W. Jeon, M.H. Kim, B.G. Kang, Y. Jung, J. Jin, S.C. Hong, W.Y. Park, D.S. Lee, H. Kim, and D.H. Nam, Clinical and biological implications of CD133-positive and CD133-negative cells in glioblastomas. Lab. Invest. 88 (2008) 808-815

[42] G.H. Heppner, Tumor heterogeneity. Cancer Res. 44 (1984) 2259-2265. 
[43] M.E. Laughlin-Drubin, K. Munger. Viruses associated with human cancer. Biochim. Biophys. Acta (2008) 178 127-150.

[44] R. Pardal, M.F. Clarke, and S.J. Morrison, Applying the principles of stem-cell biology to cancer. Nat. Rev. Cancer 3 (2003) 895-902.

[45] I.J. Fidler, S. Yano, R.D. Zhang, T. Fujimaki, and C.D. Bucana, The seed and soil hypothesis: vascularisation and brain metastases. Lancet Oncol. 3 (2002) 53-57.

[46] A.M. Soto, and C. Sonnenschein, The somatic mutation theory of cancer: growing problems with the paradigm? Bioessays 26 (2004) 1097-1107.

[47] C. Sonnenschein, and A.M. Soto, Theories of carcinogenesis: An emerging perspective. Semin Cancer. Biol. 18 (2008) 372-377.

[48] A. Albini, and M.B. Sporn, The tumour microenvironment as a target for chemoprevention. Nat Rev Cancer 7 (2007) 139-47.

[49] J.A. Joyce, Therapeutic targeting of the tumor microenvironment. Cancer Cell 7 (2005) 513520.

[50] R. Kalluri, and M. Zeisberg, Fibroblasts in cancer. Nat. Rev. Cancer 6 (2006) 392-401.

[51] P.A. Kenny, and M.J. Bissell, Tumor reversion: correction of malignant behavior by microenvironmental cues. Int. J. Cancer 107 (2003) 688-695.

[52] M.J. Hendrix, E.A. Seftor, R.E. Seftor, J. Kasemeier-Kulesa, P.M. Kulesa, and L.M. Postovit, Reprogramming metastatic tumour cells with embryonic microenvironments. Nat. Rev. Cancer 7 (2007) 246-255.

[53] A. Sica, P. Allavena, A. Mantovani, Cancer related inflammation: the macrophage connection. Cancer Lett. 264 (2008) 204-215.

[54] L. Cegelski, G.R. Marshall, G.R. Eldridge, and S.J. Hultgren, The biology and future prospects of antivirulence therapies. Nat. Rev. Microbiol. 6 (2008) 17-27.

[55] R.L. Nagel. Epistasis and the genetics of human diseases. C. R. Biol. 328 (2005).606-615. 
